\title{
Penetrating cardiac trauma in stab wounds: A study of diagnostic accuracy of the cardiac area
}

\author{
Jorge Hernan Montenegro Muñoz, M.D., ${ }^{1}$ Oscar Dussan, M.D., ${ }^{2}$ ○ Francisco Ruiz, M.D., ${ }^{3}$ \\ 다 Andres M. Rubiano, M.D., ${ }^{4}$ 당 Juan C. Puyana, M.D. ${ }^{5}$
}

\author{
${ }^{1}$ Meditech Foundation, Clinical Research Group, Neiva-Colombia \\ ${ }^{2}$ Department of General Surgery, South Colombian University, Neiva-Colombia \\ ${ }^{3}$ Department of General Surgery, South Colombian University/Hernando Moncaleano Hospital, Neiva-Colombia \\ ${ }^{4}$ Meditech Foundation / El Bosque University, Neurosciences Institute, Bogota-Colombia \\ ${ }^{5}$ Department of Surgery, Division of Trauma, University of Pittsburgh, Pittsburgh-USA
}

\begin{abstract}
BACKGROUND: Stab wounds (SW) to the thorax raises suspicion for cardiac injuries; however, the topographic description is variable. The present study aims to evaluate different topographical descriptions within the thorax and establish their diagnostic value in penetrating cardiac trauma by SW.
\end{abstract}

METHODS: Medical records of all patients admitted to our center with thoracic SW from January 2013 to June 2016 were included in this study. Diagnostic value potential was measured using different areas of the thorax described in the literature.

RESULTS: In this study, we analyzed 306 cases. Thirty-eight (12.4\%) patients had a cardiac injury managed surgically. Death by cardiac injury occurred in seven (18.4\%) patients. The cardiac area defined between the right mid-clavicle line until the left anterior axillary line, and between 2 nd and 6 th intercostal spaces was the more accurate. It has sensitivity of $97.3 \%$, specificity $72 \%$, positive predictive value $33 \%$, negative predictive value $99.4 \%$ and accuracy $75.1 \%$ for penetrating cardiac trauma. ROC was 0.894 IC $95 \%$ (0.760-0.90I).

CONCLUSION: Among the thoracic areas, topographical limits between the right mid-clavicle line and the left anterior axillary line, and between $2^{\text {nd }}$ and $6^{\text {th }}$ intercostal spaces are the more accurate and are highly indicative of cardiac injury in patients with SW to the thorax.

Keywords: Diagnosis; penetrating cardiac trauma; stab wound; trauma.

\section{INTRODUCTION}

Penetrating cardiac trauma remains an injury with high mortality but can be salvageable. Despite immense progress in the area of trauma care, more than $90 \%$ of patients may die before reaching the emergency room. ${ }^{[1,2]}$ Due to the low frequency of these cases and thus the difficulty in acquiring sufficient experience in their management, it can be easy to miss a diagnosis of cardiac injury. Penetrating cardiac injuries represent around $0.1 \%$ of all trauma admissions, representing less than 10 cases per year for the majority of hospitals in many regions of the world..$^{[3,4]}$
During the last two decades, the advent of real-time ultrasound and the use of echocardiography mode $B$ or $M$ in emergency departments has revolutionized management and algorithms for thoracic injuries, in particular those corresponding to the anterior wall of the chest. ${ }^{[5]}$ The use of Focused Assessment with Sonography for Trauma (FAST) and subxiphoid pericardial window (SPW) was introduced and led to significant changes in the timing for surgical approach, especially in centers were the initial diagnosis was routinely performed clinically. ${ }^{[6]}$ In countries with a high incidence of violence like Colombia, early case series noted that $85 \%$ of the penetrating injuries were stab wounds (SW) and $12 \%$

Cite this article as: Muñoz JHM, Dussan O, Ruiz F, Rubiano AM, Puyana JC. Penetrating cardiac trauma in stab wounds: A study of diagnostic accuracy of the cardiac area. Ulus Travma Acil Cerrahi Derg 2020;26:693-698.

Address for correspondence: Jorge Hernan Montenegro Muñoz, M.D.

Calle 7A\#44-95 760036 Cali - Colombia

Tel: +573006154775 E-mail: jorgehmontenegrom@gmail.com

Ulus Travma Acil Cerrahi Derg 2020;26(5):693-698 DOI: 10.14744/tjtes.2020.70503 Submitted: 04.08.2018 Accepted: 02.02.2020 Online: 10.09.2020

Copyright 2020 Turkish Association of Trauma and Emergency Surgery 
were from firearms. ${ }^{[5,7]}$ However, in studies performed, more recently, $47 \%$ of the wounds were SW and $42 \%$ from a firearm, with mortality levels from a firearm being the highest. ${ }^{[8]}$

Publications from countries with low volumes of chest trauma have been published, including numbers like 14 cases over 20 years, highlighting that cardiac injuries are relatively rare, but with high mortality, requesting the application of clear guidelines with the aim of improving the survival of the patients. ${ }^{[9]}$ However, there is not yet a statistically validated definition for the different "Cardiac areas" or "Cardiac Box" found in the literature, making it difficult to design diagnostic and management protocols for penetrating stab wounds in cardiac trauma. The present study aims to evaluate different topographic descriptions of the thorax and cardiac area and establish their diagnostic value for cardiac injury in penetrating trauma.

\section{MATERIALS AND METHODS}

This study was approved by the local Ethics Committee and conformed to the principles of the Declaration of Helsinki.

\section{Study Design}

A cross-sectional retrospective study was conducted reviewing medical records of patients admitted to Neiva University Hospital with SW, which caused the thoracic penetrating injury (TPI) during the period from 2013 to 20I6. This was defined as an injury that penetrates the pleural or pericardial cavity.

Inclusion criteria

I. Patient with an SW in the anterior or posterior region of the thorax.

2. Age older than 14 years.

3. Admission during the period of evaluation.

Exclusion criteria

I. Tangential or superficial SW.

2. Patients who arrived without signs of life.

3. Incomplete information in physical and electronic medical records.

4. Pregnancy

\section{Test Methods}

A review of the literature was conducted to determine the different topographical areas of the thorax that were described when attempting to determine the possibility of cardiac injury from an SW. We found two different descriptions that were used by different national and international studies. These areas were identified for this study as A, B and C. A new area identified as $D$ was also proposed from the pilot test carried out at the start of this research. The limits of topographical area A (the Cardiac Box ${ }^{[10]}$ ) are between the superior aspect of the clavicles and inferior costal margin, including the epigastrium, and between the two mid-clavicular lines. Topographical area B (the Cambridge-anatomical area $\left.{ }^{[\prime \prime}\right]$ ) is located from the 3 rd to the 6th intercostal space on the right sternal edge and the left from the 2 nd intercostal space $2 \mathrm{~cm}$ lateral to the sternal border until the 5 th intercostal space in the midclavicular line. Topographical area C (Cardiac Zone ${ }^{[12]}$ ) is located from right anterior axillary line anteriorly across the precordium to the posterior left chest ending in the midline at the spinous processes, with the superior margin being the supraclavicular areas and the inferior margin being the costal margins, including the upper epigastrium. Topographical area D (proposed area) is located from the 2 nd to the 6 th intercostal space between the right midclavicular line and the left anterior axillary line.

The gold standard for confirmation of cardiac injury was surgical findings. In those patients who had no cardiac injury, this was confirmed by Echocardiogram, FAST, SPW or chest x-ray in order to give satisfactory confirmation of the absence of injury. This information was confirmed through the medical records, imaging studies and surgical reports.

\section{Statistical Analysis}

Data were expressed as the mean value and its standard deviation. The diagnostic value for cardiac injury of each topographical thoracic area was calculated using sensitivity, specificity, accuracy, positive predictive value, negative predictive value, positive likelihood ratio, negative likelihood ratio and ROC with $95 \% \mathrm{CI}$. SPSS software (SPSS version 19, Chicago, IL, United States) was applied for statistical analyses.

\section{RESULTS}

After reviewing the medical record of the 306 patients, 38 patients were found with cardiac injury diagnosed during the surgical intervention to be included in this study (Fig. I).

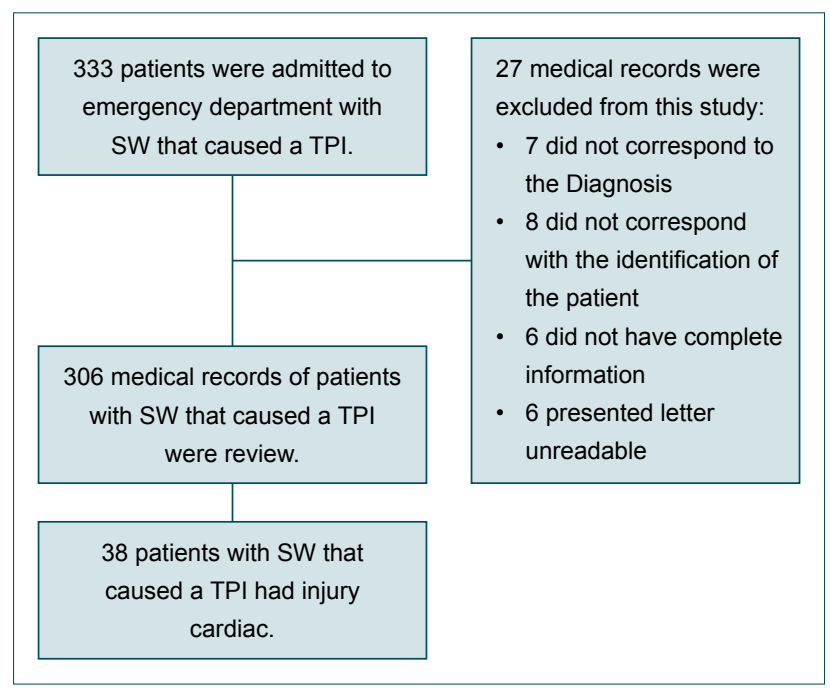

Figure 1. Flow of participants in this study. SW: Stab wounds; TPI: Thoracic penetrating injury. 
Table I. Distribution of the patient with penetrating cardiac injury

\begin{tabular}{|c|c|c|c|}
\hline Variable & $\begin{array}{l}\text { Survivor } \\
\text { n }(\%)=31\end{array}$ & $\begin{array}{c}\text { Die } \\
\text { n }(\%)=7\end{array}$ & $\begin{array}{c}\text { Total } \\
\text { n }(\%)=38\end{array}$ \\
\hline \multicolumn{4}{|l|}{ Admission data } \\
\hline Age (year) & $29.7 \pm 9.7$ & $41.1 \pm 18.6$ & $31.8 \pm 11.5$ \\
\hline Sex (male/female) & $30 / 1$ & $5 / 2$ & $35 / 3$ \\
\hline Systolic pressure blood (mmHg) & $86.1 \pm 25.5$ & $40.5 \pm 41$ & $77.7 \pm 33.5$ \\
\hline Heart rate (bpm) & $101 \pm 23.8$ & $76.8 \pm 53.9$ & $96.5 \pm 32$ \\
\hline Shock index & 1.3 & 2.9 & 1.4 \\
\hline Injury Severity Score & $18 \pm 8.5$ & $44 \pm 15.2$ & $30 \pm 12.3$ \\
\hline \multicolumn{4}{|l|}{ Diagnosis, n (\%) } \\
\hline Surgery & $19(61.3)$ & $7(100)$ & $26(68.4)$ \\
\hline Focused assessment with sonography for trauma & $6(19.4)$ & 0 & $6(15.8)$ \\
\hline Subxiphoid pericardial window & $5(16.1)$ & 0 & $5(13.2)$ \\
\hline Echocardiogram & I (3.2) & 0 & I (2.6) \\
\hline \multicolumn{4}{|l|}{ Cardiac injury, n (\%) } \\
\hline Right atrium & $4(12.9)$ & I (I4.3) & $5(13.2)$ \\
\hline Right ventricle & $20(64.5)$ & $4(57.1)$ & $24(63.2)$ \\
\hline Left atrium & I (3.2) & 0 & I (2.6) \\
\hline Left ventricle & $6(19.4)$ & $2(28.6)$ & $8(2 I .1)$ \\
\hline Size of cardiac lesion (mm) & $15.5 \pm 10.1$ & $31.7 \pm 16.5$ & $18.9 \pm 12.2$ \\
\hline
\end{tabular}

The majority of patients were male [292 (95.4\%)]; the average age was $30.4 \pm \mathrm{I} 1.6$ years, a median of 28 years, the minimum age was 15 and maximum of 75 years. 38 (12.4\%) of the patients were identified with cardiac Injury, all injuries being located in the anterior wall of the thorax; the average age of these patients was $31.8 \pm 11.5$ years, minimum age of 15 and maximum of 60 years and 35 (92.1\%) were men. At



Figure 2. Relationship between areas evaluated and the topographical location of the lesions in the thorax. Non mortal Injuries (yellow points) and mortal injuries (red points). Area A (yellow box), area $\mathrm{B}$ (blue box), area $\mathrm{C}$ (orange box) and area $\mathrm{D}$ (green box). admission to the emergency department, systolic blood pressures mean (SBP) was $77.7 \pm 33.5 \mathrm{mmHg}$ and the mean heart rate $(H R)$ was $96.5 \pm 32$ beats per minute; the shock index (SI) average was I.4. The location of the lesions to the heart was in $24(63.2 \%)$ cases the right ventricle, five (13.2\%) cases in the right atrium, $8(21.1 \%)$ in the left ventricle and I $(3.3 \%)$ in the left atrium. The average size of the cardiac lesions was


es; $4(57.1 \%)$ had a lesion to the right ventricle, $2(28.5 \%)$ to the left ventricle and I (I4.2\%) to the right atrium (Table I). The following table shows an analysis of the patients within the study, their injuries and outcomes (Fig. 2).

The diagnostic value for cardiac injury of each topographical thoracic areas evaluated is described in the following Table (Table 2).

\section{DISCUSSION}

A high clinical suspicion of cardiac injury $(\mathrm{Cl})$, which occurs in the $6.4 \%$ stab wounds to the chest, ${ }^{[13]}$ is important due to the high mortality and the increase in survival rates if intervention comes early. In low and middle-income countries centers without access to radiological studies are still the primary location for the diagnosis and management of these injuries. $[14,15]$ The cardiac area has an important clinical significance due to its ability to help in the development of management algorithms with or without the use of technologies for imag- 
Table 2. Description of the diagnostic value for $\mathrm{Cl}$ of each topographical thoracic area evaluated

\begin{tabular}{lccccccccc}
\hline Area evaluated & SEN (\%) & SPE (\%) & VPP (\%) & VPN (\%) & Accuracy (\%) & LR + & LR - & AUC ROC & IC 95\% \\
\hline Area A & 89.4 & 66.4 & 27.4 & 97.8 & 69.2 & 2.6 & 0.1 & 0.779 & $0.710-0.849$ \\
Area B & 55.2 & 86.5 & 36.8 & 93.1 & 82.6 & 4.1 & 0.5 & 0.709 & $0.610-0.808$ \\
Area C & 100 & 17.9 & 14.7 & 100 & 28.1 & 1.2 & 0 & 0.590 & $0.505-0.674$ \\
Area D & 97.3 & 72 & 33 & 99.4 & 75.1 & 3.47 & 0.03 & 0.847 & $0.797-0.897$
\end{tabular}

SEN: Sensitivity; SPE: Specificity, PPV: Positive predictive value; NPV: Negative predictive value; LR+: Positive likelihood ratio; LR-: Negative likelihood ratio; AUC ROC: Area under curve ROC.

ing (FAST, SPW, thoracoscopy). Given that decision-making should be done quickly to reduce mortality in this type of injury, it is important to define the limits of this area as a diagnostic screening test. In a review of the literature, studies evaluating their diagnostic value are not easy to find. The area has been previously referred to as the "cardiac proximity", ${ }^{[16]}$ "cardiac box", ${ }^{[10]}$ "heart silhouette", ${ }^{[17]}$ "precordium" and "cardiac zone", ${ }^{12]}$ terms all used to describe an area of the thorax in which the penetrating wounds are at risk of causing injury to the heart. ${ }^{[18]}$

The population in this study is similar to the population described in other studies, being mostly male and of an economically active age..$^{[9,10,12,14]}$ The site more affected in the heart is the right ventricle by its previous position with similar frequency to the literature (62\%), followed by the left ventricle that causes high mortality. ${ }^{[19-21]}$ Mortality reported in studies of $\mathrm{Cl}$ secondary to stab wounds is on average $21.9 \%$ (range $8-22 \%)$ which is higher than the mortality found in our study (18.4\%) and higher than other mortality described in other Colombian trauma centers (8.8\%). ${ }^{[14]}$ Most of the patients in our study reached the hospital in a haemodynamically unstable state and with a $\mathrm{Cl}$ greater than $30 \mathrm{~mm}$.

Different methods diagnostics (creatine kinase (CK)-MB or CKMB ratio, troponin I and troponin T, electrocardiogram) have been evaluated remain limited to its value diagnosis and applied with greater frequency in patients with blunt cardiac injuries and hemodynamically stable. ${ }^{[22-24]}$ Focused assessment with sonography for trauma patients (FAST) and the Focused cardiac ultrasound (FOCUS) have been associated with a decrease of mortality as it leads to early diagnosis and timely management. ${ }^{[6,25]}$ Most of these studies have been conducted to evaluate ultrasound methods and include multiples types of injuries like knives and firearms. According to these studies, two-thirds of the patients with a $\mathrm{Cl}$ have entry wounds into the skin between the left anterior axillary line and the left sternal edge. ${ }^{[26]}$ Another study shows the highest mortality from cardiac injury by stab wounds outside of the precordial region (25\%), in contrast, to stab wounds located in the cardiac area (4\%). In these studies, they recommend a re-thinking of the actual cardiac areas described in the thorax to improve the index of suspicion for the detection of $\mathrm{Cl}$ and recommend a new "Cardiac zone". ${ }^{[12,27]}$

On assessing the diagnostic value of the three areas, it was shown that the cardiac area described as the Cambridge anatomical area (Area B) had lower sensitivity but a higher specificity $(86.5 \%)$ than the other areas. Nicol et al. ${ }^{[2]}$ proposes an area (Area $\mathrm{C}$ ) that was evaluated with sensitivity and negative predictive value perfect (100\%), despite which would exclude the wound outside the thorax as possible cardiac injury should be considered a small area with similar value diagnosis to suspect a cardiac injury taking considerations about the trauma mechanism as described the literature. In two cases reported, the lesions are located lateral to the right mid-clavicular line and another superior to the left clavicle suggesting that $\mathrm{Cl}$ should be anticipated even when a wound is not in the cardiac area. ${ }^{[28]}$

This type of injury requires that the defined cardiac area has adequate sensitivity and NPV to guide the management. In comparison with the previously defined areas, the area described by the new proposal (area D) was found to have a sensitivity of $97.3 \%$, a VPN of $99.4 \%$, and an improved area under the curve ROC $(0.847 \mathrm{CI} 95 \% 0.797-0.897)$. It is believed that this proposed "Cardiac area" can better guide the process of identifying cardiac injury in those patients with penetrating trauma to the thorax.

\section{Limitations}

The main limitation of this study is the small sample size. There is not analysis for excluded patients with incomplete data in the medical record. Further studies are required to validate our findings in a bigger population.

\section{Conclusion}

Among the thoracic areas evaluated, the topographical limits between the right midclavicular line and the left anterior axillary line and between $2^{\text {nd }}$ and $6^{\text {th }}$ intercostal spaces are the most accurate and highly indicative of cardiac injury in patients with stab wounds to the thorax.

Ethics Committee Approval: Approved by the local ethics committee. 
Peer-review: Internally peer-reviewed.

Authorship Contributions: Concept: J.H.M.M., O.D., A.M.R.; Design: J.H.M.M., O.D., A.M.R., F.R., J.C.P.; Supervision: A.M.R., F.R., J.C.P.; Materials: J.H.M.M., O.D., A.M.R., F.R., J.C.P.; Data: J.H.M.M., O.D., A.M.R., F.R., J.C.P.; Analysis: J.H.M.M., A.O., A.M.R.; Literature search: .H.M.M., O.D., A.M.R., F.R., J.C.P.; Writing: .H.M.M., O.D., A.M.R., F.R., J.C.P.; Critical revision: .H.M.M., O.D., A.M.R., F.R., J.C.P.

\section{Conflict of Interest: None declared.}

Financial Disclosure: The authors declared that this study has received no financial support.

\section{REFERENCES}

1. Campbell NC, Thomson SR, Muckart DJ, Meumann CM, Van Middelkoop I, Botha JB. Review of 1198 cases of penetrating cardiac trauma. Br J Surg 1997;84:1737-40. [CrossRef]

2. Carr JA, Buterakos R, Bowling WM, Janson L, Kralovich KA, Copeland $\mathrm{C}$, et al. Long-term functional and echocardiographic assessment after penetrating cardiac injury: 5-year follow-up results. J Trauma 2011;70:701-4. [CrossRef]

3. Morse BC, Mina MJ, Carr JS, Jhunjhunwala R, Dente CJ, Zink JU, et al. Penetrating cardiac injuries: A 36-year perspective at an urban, Level I trauma center. J Trauma Acute Care Surg 2016;81:623-31. [CrossRef]

4. Asensio JA, Garcia-Nunez LM, Petrone P, Duran D, Vara AD, Weston JS, et al. Cardiac injuries. In: Current therapy of trauma and surgical critical care. Asensio JA, Trunkey DD, editors. Philadelphia: Mosby Elsevier; 2008.p.304-15. [CrossRef]

5. Rozycki GS, Feliciano DV, Ochsner MG, Knudson MM, Hoyt DB, Davis $\mathrm{F}$, et al. The role of ultrasound in patients with possible penetrating cardiac wounds: a prospective multicenter study. J Trauma 1999;46:543-51; discussion 551-2. [CrossRef]

6. Kong VY, Oosthuizen G, Sartorius B, Sartorius B, bruce J, Clarke DL. Penetrating cardiac injuries and the evolving management algorithm in the current era. J Surg Res 2015;193:926-32. [CrossRef]

7. Ferrada R, Rodriguez A. Trauma cardiac. Rev Col Cirugia 2001;16:5-15.

8. Karrel R, Shaffer MA, Franaszek JB. Emergency diagnosis, resuscitation, and treatment of acute penetrating cardiac trauma. Ann Emerg Med 1982;11:504-17. [CrossRef]

9. Ngatchou W, Surdeanu I, Ramadan AS, Essola B, Youatou P, Guimfacq V, et al. Penetrating cardiac injuries in Belgium: 20 years of experience in university hospitals in Brussels. Acta Chir Belg 2013;113:275-80. [CrossRef]

10. Asensio JA, Stewart BM, Murray J, Fox AH, Falabella A, Gomez H, et al. Penetrating cardiac injuries. Surg Clin North Am 1996;76:685-724.

11. Wilcox BR, Cook AC, Anderson RH. Surgical anatomy of the heart. 3rd edition. Cambridge, UK: Cambridge University Press; 2005.
12. Nicol AJ, Navsaria PH, Beningfield S, Hommes M, Kahn D. Screening for occult penetrating cardiac injuries. Ann Surg 2015;261:573-8.

13. Asensio JA, Roldan G, Petrone P, Forno W, Rowe V, Salim A. Cardiac Trauma. J Trauma 2001;3:69-77. [CrossRef]

14. Hernandez F, Correa J. Trauma Precordial Penetrante ¿Ventana Pericárdica vs Eco?. [Article in Spanish]. Colombia: Universidad del Valle press, 2010.

15. Moore H, Demner S, Caro A. Trauma Precordial. [Article in Spanish]. Rev Col Cirugia 1989;17:23.

16. Meyer DM, Jessen ME, Grayburn PA. Use of echocardiography to detect occult cardiac injury after penetrating thoracic trauma: a prospective study. J Trauma 1995;39:902-9. [CrossRef]

17. Grewal H, Ivatury RR, Divakar M, Simon RJ, Rohman M. Evaluation of subxiphoid pericardial window used in the detection of occult cardiac injury. Injury 1995;26:305-10. [CrossRef]

18. Demetriades D. Cardiac wounds. Experience with 70 patients. Ann Surg 1986;203:315-7. [CrossRef]

19. Altun G, Altun A, Yilmaz A. Hemopericardium-related fatalities: a 10-year medicolegal autopsy experience. Cardiology 2005;104:133-7. [CrossRef]

20. Gosavi S, Tyroch AH, Mukherjee D. Cardiac Trauma. Angiology 2016;67:896-901. [CrossRef]

21. Ezzine SB, Bouassida M, Benali M, Ghannouchi M, Chebbi F, Sassi S, et al. Management of penetrating cardiac injuries in the Department of surgery, Mohamed Thahar Maamouri Hospital, Tunisia: report of 19 cases. Pan Afr Med J 2012;11:54.

22. Salim A, Velmahos GC, Jindal A, Chan L, Vassiliu P, Belzberg H, et al. Clinically significant blunt cardiac trauma: role of serum troponin levels combined with electrocardiographic findings. J Trauma 2001;50:237-43.

23. Clancy K, Velopulos C, Bilaniuk JW, Collier B, Crowley W, Kurek S, et al; Eastern Association for the Surgery of Trauma. Screening for blunt cardiac injury: an Eastern Association for the Surgery of Trauma practice management guideline. J Trauma Acute Care Surg 2012;73:S301-6.

24. Collins JN, Cole FJ, Weireter LJ, Riblet JL, Britt LD. The usefulness of serum troponin levels in evaluating cardiac injury. Am Surg 2001;67:821-6.

25. Mandavia DP, Hoffner RJ, Mahaney K, Henderson SO. Bedside echocardiography by emergency physicians. Ann Emerg Med 2001;38:377-82.

26. Seamon MJ, Haut ER, Van Arendonk K, Barbosa RR, Chiu WC, Dente $\mathrm{CJ}$, et al. An evidence-based approach to patient selection for emergency department thoracotomy: A practice management guideline from the Eastern Association for the Surgery of Trauma. J Trauma Acute Care Surg 2015;79:159-73. [CrossRef]

27. Stranch EW, Zarzaur BL, Savage SA. Thinking outside the box: re-evaluating the approach to penetrating cardiac injuries. Eur J Trauma Emerg Surg 2017;43:617-22. [CrossRef]

28. Claassen CW, O'connor JV, Gens D, Sikorski R, Scalea TM. Penetrating cardiac injury: think outside the box.J Trauma 2010;68:E71-3. [CrossRef] 


\section{ORİJINAL ÇALIŞMA - ÖZET}

\section{Kesici-delici alet yaralanmalarında penetran kardiyak travma: Kardiyak bölgenin doğru tanısına ilişkin bir çalışma \\ Dr. Jorge Hernan Montenegro Muñoz, ${ }^{1}$ Dr. Oscar Dussan, ${ }^{2}$ Dr. Francisco Ruiz, ${ }^{3}$ \\ Dr. Andres M Rubiano, ${ }^{4}$ Dr. Juan C. Puyana ${ }^{5}$}

${ }^{1}$ Meditech Vakfı, Klinik Araștırma Grubu, Neiva-Kolombiya

${ }^{2}$ Güney Kolombiya Üniversitesi, Genel Cerrahi Anabilim Dalı, Neiva-Kolombiya

${ }^{3}$ Güney Kolombiya Üniversitesi / Hernando Moncaleano Hastanesi, Genel Cerrahi Anabilim Dalı, Neiva-Kolombiya

${ }^{4}$ Meditech Vakfı / El Bosque Üniversitesi, Nörobilim Enstitüsü, Bogota-Kolombiya

${ }^{5}$ Pittsburgh Üniversitesi, Cerrahi Anabilim Dalı, Travma Bölümü, Pittsburgh-ABD

AMAÇ: Torakstaki kesici ve delici alet yaralanmaları (SW) kardiyak yaralanma şüphesini akla getirmekle beraber bunlara ilişkin tomografik açıklamalar değişkenlik gösterir. Bu çalışma, toraks içindeki farklı tomografik tanımlamaları değerlendirilmesi ve SW'nin penetran kardiyak travmasındaki tanı değerlerinin saptanması amaçlanmaktadır.

GEREÇ VE YÖNTEM: Ocak 2013 - Haziran 2016 tarihleri arasında merkezimize torasik SW ile başvuran tüm hastaların tıbbi kayıtları bu çalışmaya alındı. Bunların tanı değeri potansiyelleri literatürde açıklanan farklı toraks alanları kullanılarak ölçüldü.

BULGULAR: Üç yüz altı olgu analiz edildi. Otuz sekiz (\%।2.4) hastada cerrahi olarak yönetilen kalp yaralanması vardı. Kardiyak yaralanma nedeniyle ölüm 7 (\%।8.4) hastada meydana geldi. Sağ ön klavikula çizgisi ile sol ön aksiller çizgiye kadar, 2. ve 6. interkostal boşluklar arasında tanımlanan kalp alanı daha doğruydu. Penetran kardiyak travmada \%97.3, özgüllük \%72, pozitif prediktif değer \%33, negatif prediktif değer \%99.4 ve \%75.। hassasiyete sahiptir. ROC 0.894 IC \%95 (0.760-0.90I) idi.

TARTIŞMA: Torasik bölgeler arasında, sağ orta klavikula çizgisi ile sol ön aksiller çizgisi ve 2. ve 6. interkostal boşluklar arasındaki topografik sınırlamalar daha kesindir ve toraks ile SW hastalarında kalp yaralanmasının yüksek göstergesidir.

Anahtar sözcükler: Penetran kalp travması; stab yara; tanı; travma.

Ulus Travma Acil Cerrahi Derg 2020;26(5):693-698 doi: 10.14744/tjtes.2020.70503 